\title{
The role of Eudiplodinium maggii in starch metabolism in the rumen ${ }^{*}$
}

\author{
G. Belżecki and T. Michałowski \\ The Kielanowski Institute of Animal Physiology and Nutrition, \\ Polish Academy of Sciences \\ 05-110 Jablonna, Poland
}

\begin{abstract}
Amylolytic activity was examined in the rumen of three Polish Merino sheep that were ciliatefree or refaunated with Eudiplodinium maggii. The rate of reducing sugars release from starch by the enzymes extracted from rumen digesta of defaunated and refaunated sheep was 7.1-14.2 and 8.7$19.5 \mu \mathrm{M} / \mathrm{g}$ DM digesta/min, respectively. A significant increase in amylolytic activity was observed after feeding, regardless of the presence or absence of ciliates. Reducing sugars released from starch by enzymes extracted from the cells of Eudiplodinium maggii were about $161-183 \mu \mathrm{M} / \mathrm{g}$ protozoal $\mathrm{DM} / \mathrm{min}$. Neither protozoal activity nor numbers changed significantly after feeding $(\mathrm{P}<0.05)$. Ciliates readily ingested starch grains and $89 \%$ protozoa cells were filled with this polysaccharide at $4 \mathrm{~h}$ after feeding. Only 6.5 and $8.9 \mathrm{~g}$ of 1,$4 ; 1,6-\alpha$-D-glucan were found in the rumen $12 \mathrm{~h}$ after feeding defaunated and refaunated sheep, respectively. These values were equivalent to 10.8 and $14.7 \%$ starch present in ground barley given to animals in the ration.
\end{abstract}

KEY WORDS: sheep, defaunation, amylolytic activity, Eudiplodinium maggii

\section{INTRODUCTION}

Starch is the nutritionally most important reserve polysaccharide in grain and/ or concentrate diet. It is readily digested and fermented in the rumen by a variety of rumen microorganisms (Chesson and Forsberg, 1997). Of protozoa, the Entodinium species seems to prefer this carbohydrate to satisfy its energy requirements, but large ophryoscolecids also easily engulf starch grains. The importance of cili-

\footnotetext{
* Supported by the State Committee for Scientific Research, Grant No. 5 PO6E03615
} 
ates to starch digestion in the rumen is not clear. For example, Mendoza et al. (1993) found that establishment of protozoal populations in the rumen of defaunated sheep decreased starch digestion. In contrast, Veira et al. (1983) observed an increase in this process in the presence of protozoa. Natural rumen fauna is composed of numerous species of ciliates that are involved in starch metabolism (Williams and Coleman, 1992). Review of the available literature has shown, however, that the role of individual species of protozoa in starch metabolism in the rumen has only been sporadically examined (Veira et al., 1983; Coleman, 1986).

The objectives of this investigation were to study the amylolytic activity in the rumen content of sheep defaunated and refaunated with Eudiplodinium maggii, as well as starch engulfment by ciliates established in the rumen and disappearance of 1,4;1,6- $\alpha$-D-glycan from the rumen of defaunated and refaunated sheep.

\section{MATERIAL AND METHODS}

Three male Polish Merino sheep, weighing about $40 \mathrm{~kg}$, fitted with large rumen cannulae were used. The animals were kept in separate pens with solid walls. They were fed $750 \mathrm{~g}$ hay and $130 \mathrm{~g}$ ground barley every $12 \mathrm{~h}$ and had free access to water. The sheep were defaunated about 40 days before the study was begun by the method of Michałowski et al. (1999)

The study comprised two experimental periods during which the sheep were either ciliate-free (period 1) or possessed an established population of Eudiplodinium maggii (period 2).

Samples for determination of enzyme activity $(2 \times 60-70 \mathrm{~g})$ and protozoa counts $(2 \times 5 \mathrm{~g})$ were taken from the rumen just before the morning feeding ( $8 \mathrm{a} . \mathrm{m}$.) and at 4,8 and $12 \mathrm{~h}$ thereafter. Samples of rumen digesta to prepare a purified suspension of ciliates (approximately $1 \mathrm{~kg}$ ) were taken before morning feeding and at 2, 4,6, 8 and $10 \mathrm{~h}$ after feeding. Digesta volume was estimated just before both the morning and evening feeding. This was done by cvacuation and weighing of the rumen contents. Each sampling was repeated three times on different days of each experimental period.

To prepare the suspension of purified protozoa the rumen content samples were diluted with warm $\left(40^{\circ} \mathrm{C}\right)$, caudatum " type medium for culture of rumen ciliates (Coleman et al., 1972) at a proportion of $1: 2(\mathrm{w} / \mathrm{v})$ and squeezed through a screen of pore size $0.5 \mathrm{~mm}$. The liquid fraction was collected, poured into a separatory funnel and allowed to stand at $40^{\circ} \mathrm{C}$ for $30-40$ min to sediment the ciliates. The sedimented protozoa were collected and purified according to Michałowski (1990). Finally the suspension of ciliates was adjusted to a volume of $100 \mathrm{ml}$ and sampled $(5 \mathrm{ml})$ for protozoa counting while the remaining part was lyophilized by freezing in a vacuum and stored at $-20^{\circ} \mathrm{C}$. 
Enzymes were extracted from digesta samples and lyophilized protozoa according to Huhtanen and Khalili (1992) by the use of carbon tetrachloride and lysozyme. Amylolytic activity was determined by measurement of the reducing sugars released from soluble starch ( $0.4 \%$ solution) during its incubation with the extracted enzymes at $40^{\circ} \mathrm{C}$ for $1 \mathrm{~h}$, according to Groleau and Forsberg (1981) and Huhtanen and Khalili (1992). The activity was expressed as $\mu \mathrm{M}$ reducing sugars released from substrate/g DM/min. Starch in the rumen content was estimated following hydrolysis of digesta with $\alpha$-amylase and glucoamylase, according to AOAC (1990). Glucose and reducing sugars were measured by the anthrone method and dinitrosalicilic acid reagent (Miller et al., 1960), respectively. Ciliates were counted under a light microscope (Michałowski, 1990).

Mean values were calculated and compared by Student's t-test.

\section{RESULTS AND DISCUSSION}

Amylolytic activity in rumen digesta varied in the range of $8.1-19.5 \mu \mathrm{M}$ reducing sugars/g DM/min (Table 1). Coleman (1986) examined starch and amylose degradation in defaunated and differently refaunated sheep. Unfortunately, the enzyme activities were expressed there as $\mu \mathrm{M}$ maltose $/ \mathrm{ml}$ of rumen fluid. Due to this the results obtained by the cited author are hardly comparable with those presented in this report.

Starch degrading enzymes extracted from purified cells of Eudiplodinium maggii released up to $180 \mu \mathrm{M}$ reducing sugars $/ g$ protozoal $\mathrm{DM} / \mathrm{min}$. This value, expressed as product quantity per $\mathrm{mg} \mathrm{DM}$ per $\mathrm{h}$, agrees well with the findings of Coleman (1986).

Amylolytic activity in the rumen content increased with time and was the highest at $4 \mathrm{~h}$ after feeding (Table 1 ). This increase could be the result of changes in the number or/and in the activity of bacteria since it was observed both in the presence and absence of Eudiplodinium maggii in the rumen. Lack of changes in either numbers or protozoal amylase activity observed at the same time supports this suggestion.

It was found that Eudiplodinium maggii readily and quickly engulfed starch and $88 \%$ of ciliates were observed with numerous grains of this polysaccharide in endoplasmic sacs already $2 \mathrm{~h}$ after giving feed to sheep (Figure 1). Starch granules disappeared gradually from the cells during the last $8 \mathrm{~h}$ after feeding, presumably due to digestion processes. Some protozoa taken from the rumen just before the next feeding possessed undigested starch inside the cells. This observation could confirm the opinion that ciliates slow starch fermentation in the rumen (Mendoza et al., 1993). 
TABLE 1

Amylolytic activity in defaunated and refaunated with Eudiplodinium maggii sheep ( $\mu \mathrm{M}$ reducing sugars/g DM rumen content/min) as well as amylase activity in purified protozoa ( $\mu \mathrm{M}$ reducing sugars $/ \mathrm{g}$ protozoal $\mathrm{DM} / \mathrm{min})$ and ciliate numbers in the rumen $\left(\times 10^{3} / \mathrm{g}\right)$

\begin{tabular}{|c|c|c|c|c|c|}
\hline \multirow{2}{*}{ Item } & \multicolumn{4}{|c|}{ Hours after feeding } & \multirow{2}{*}{ SE } \\
\hline & 0 & 4 & 8 & 12 & \\
\hline \multicolumn{6}{|l|}{ Amylase activity } \\
\hline defaunated sheep & $7.9^{\mathrm{a}}$ & $14.2^{\mathrm{b}}$ & $13.0^{\mathrm{b}}$ & $7.1^{\mathrm{a}}$ & 0.74 \\
\hline refaunated sheep & $8.7^{\mathrm{a}}$ & $19.5^{b}$ & $11.4^{\mathrm{c}}$ & $10.0^{\mathrm{bc}}$ & 0.86 \\
\hline protozoa & $162.1^{\mathrm{a}}$ & $162.3^{\mathrm{a}}$ & $183.3^{\mathrm{a}}$ & ND & 7.28 \\
\hline Protozoa number & $21.5^{\mathrm{a}}$ & $22.1^{\mathrm{a}}$ & $28.6^{\mathrm{a}}$ & $27.2^{\mathrm{a}}$ & 2.35 \\
\hline
\end{tabular}

ND - not determined

values in a row with different letters differ significantly

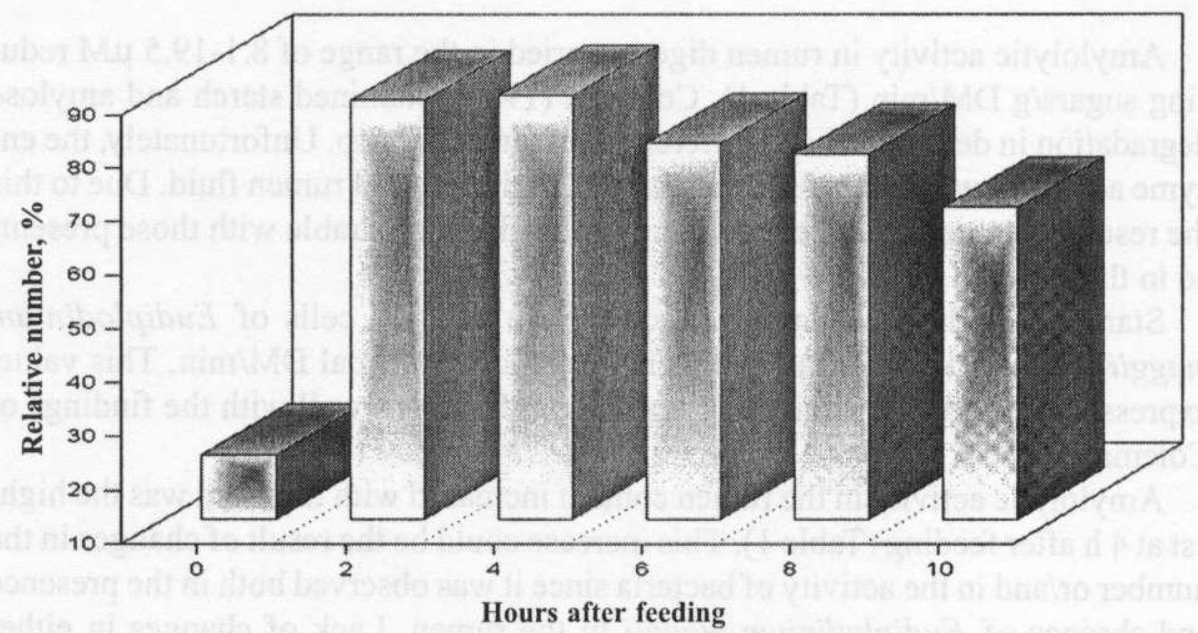

Figure 1. Changes in percentage of Eudiplodinium maggii filled with starch grains observed after feeding of sheep

It was found that of the starch given to the sheep in the ration, only $4.5-11.3 \mathrm{~g}$ was found in the rumen $12 \mathrm{~h}$ after feeding. Mean values are presented in Table 2 together with amylolytic activity. In contrast with the findings of Mendoza et al. (1993), refaunation raised the activity of enzymes involved in starch degradation. The difference could result from the fact that activity of the enzymes was not expressed here per mg protein but per $\mathrm{g}$ DM digesta. The amount of detected starch 
TABLE 2

Amylolytic activity ( $\mu \mathrm{M}$ reducing sugars $/ g$ DM rumen content $/ \mathrm{min}$ ) and starch quantity $(\mathrm{g} / \mathrm{rumen})$ in rumen of ciliate-free and refaunated with Eudiplodinium maggii sheep at $12 \mathrm{~h}$ after feeding

\begin{tabular}{lccc}
\hline Item & Ciliate free & + Eudiplodinium maggii & SE \\
\hline Amylolytic activity & $10.5^{\mathrm{a}}$ & $13.1^{\mathrm{b}}$ & 0.56 \\
Starch quantity & $6.5^{\mathrm{a}}$ & $8.9^{\mathrm{a}}$ & 0.49 \\
\hline
\end{tabular}

values in a row with different letters differ significantly

also tended to be larger in refaunated sheep $(\mathrm{P}<0.1)$. This disagreement could be explained by the fact that a part of 1,$4 ; 1,6-\alpha$-D-glucan identified in the rumen of sheep with an established population of Eudiplodinium maggii was the reserve polysaccharide synthesized by ciliates from digested dietary starch (Wakita and Hoshino, 1980). Unfortunately, the ingested starch and synthesized protozoal glycogen were not distinguished here.

\section{REFERENCES}

AOAC, 1990. Association of Official Analytical Chemists, Official Methods of Analysis. $15^{\text {th }}$ Edition. Arlington, VA

Chesson A., Forsberg C.W., 1997. Polysaccharide degradation by rumen microorganisms. In: P.N. Hobson, C.S. Stewart (Editors). The Rumen Microbial Ecosystem. Blackie Academic and Professional, London, pp. 329-381

Coleman G.S., 1986. The amylase activity of 14 species of endodiniomorphid protozoa and the distribution of amylase in digesta fractions of sheep containing no protozoa or one of seven different protozoal populations. J. Agr. Sci. 107, 709-721

Coleman G.S., Davies J.I, Cash M.A., 1972. The cultivation of the rumen ciliates Epidinium ecaudatum caudatum and Polyplastron multivesiculatum in vitro. J. Gen. Microbiol. 75, 509-521

Groleau D., Forsberg C.W., 1981. Cellulolytic activity of the rumen bacterium Bacteroides succinogenes. Can. J. Microbiol. 27, 517-530

Huhtanen P.P., Khalili H., 1992. The effect of sucrose supplements on the particle-associated carboxymethylcellulose (EC 3.2.1.4) and xylanase (EC 3.2.1.8) activities in cattle given grasssilage-based diet. Brit. J. Nutr. 67, 245-255

Mendoza G.D., Britton R.A., Stock R.A., 1993. Influence of ruminal protozoa on site and extent of starch digestion and ruminal fermentation. J. Anim. Sci. 71, 1572-1578

Michałowski T., 1990. The synthesis and turnover of the cellular matter of ciliates in the rumen. Acta Protozool. 29, 47-72

Michałowski T., 1999. The importance of washing the omasum for successful defaunation of sheep. J. Anim. Feed Sci. 8, 611-619

Miller G.L., Blum R., Glennon W.E. Burton A.L., 1960. Measurement of carboxymethylcellulase activity. Analyt. Biochem. 2, 127-132 
Veira D.M., Ivan M., Jui P.Y., 1983. Rumen ciliate protozoa: effects on digestion in the stomach of sheep. J. Dairy Sci. 66, 1015-1022

Wakita M., Hoshino S., 1980. Physiochemical propertics of a reserve polysaccharide from sheep rumen ciliate genus Entodinium. Comp. Biochem. Physiol. 65B, 571-574

Williams A.G., Coleman G.S., 1992. The Rumen Protozoa. Springer Verlag, New York, Berlin

\section{STRESZCZENIE}

\section{Rola Eudiplodinium maggii w przemianach skrobi w żwaczu}

Badano aktywność amylolityczną w żwaczu trzech owicc po defaunacji i po rozwoju populacji Eudipolodinium maggii. Tempo uwalniania cukrów redukujących ze skrobi przez enzymy wyekstrachowane $z$ treści żwacza defaunowanych i refaunowanych owiec wynosiło, odpowiednio, 7,1-14,2 i $8,7-19,5 \mu \mathrm{M} / \mathrm{g}$ suchej masy treści/min. Stwierdzono statystycznie istotny przyrost aktywności amylolitycznej po karmieniu tak w obecności jak i przy braku orzęsków. Ilość cukrów redukujących uwolnionej ze skrobi przez enzymy wyekstrachowane z komórek Eudiplodinium maggii wyniosła 161-183 $\mu \mathrm{M} / \mathrm{g}$ suchej masy orzęsków/min. Nie stwierdzono istotnych zmian liczby i aktywności pierwotniaków po karmieniu owiec. Orzęski chętnie pobierały ziarna skrobi. Stwierdzono, że $89 \%$ pierwotniaków zawierało ten węglowodan w 4 godziny po odpasie owiec. Zawartość 1,4;1,6- $\alpha$-Dglukanu w całej treści żwacza zdefaunowanych i refaunowanych owiec, wynosiła 6,5 i 8,9 g, odpowiednio, co odpowiadało 10,8 i $14,7 \%$ skrobi śruty jęczmiennej zawartej w dawce paszy. 